\title{
Strategi Guru PAI dalam Meningkatkan Minat Membaca dan Menghafal Al- Qur'an Pada Siswa di Sekolah Dasar Negeri 31 Pagaralam
}

\author{
Zelvi Fitriani \\ Mahasiswa Program Pascasarjana UIN Raden Fatah Palembang \\ Email: zelvifitriani2015@gmail.com
}

\begin{abstract}
Abstrak: Penelitian ini bertujuan untuk untuk: 1) mengetahui strategi guru PAI dalam meningkatkan minat membaca dan menghafal Alquran pada siswa di SDN 31 Pagaralam, 2) mengetahui faktorfaktor pendukung serta penghambat strategi guru PAI dalam meningkatkan minat membaca dan menghafal Alquran pada siswa di SDN 31 Pagaralam. Untuk mencapai tujuan di atas, digunakan pendekatan kualitatif dengan jenis penelitian adalah penelitian lapangan. Informan penelitan adalah Kepala Sekolah, Guru PAI serta Siswa. Hasil penelitian ini menunjukkan bahwa, 1) Strategi guru PAI dalam meningkatkan minat membaca dan menghafal Alquran pada siswa di SDN 31 Pagaralam yaitu menciptakan pembelajaran yang nyaman ketika kegiatan BTA berlangsung, memberikan motivasi kepada anak berupa penjelasan dan pengertian betapa pentingnya menghafal dan membaca Alquran untuk mereka terlebih untuk kehidupan mereka di dunia maupun di akhirat, memberikan target hafalan, melalui pembiasaan, pemberian nilai, dan terakhir pemberian penghargaan, 2) Faktor pendukung guru PAI dalam meningkatkan minat membaca dan menghafal Alquran pada siswa yaitu, peserta didik itu sendiri, peran seorang guru, fasilitas memadai, terdapat juga faktor penghambat yaitu kurangnya alokasi waktu, kurangnya kesadaran orangtua, kemudian pengaruh negatif teknologi.
\end{abstract}

\section{Kata Kunci: Strategi, Guru, Minat}

\begin{abstract}
This study aims at: 1) finding out the strategies of Islamic Religion teachers in increasing students' interest in reading and Qur'an at SDN 31 Pagaralam, 2) finding out the supporting and obstacle factors they faced in increasing students' interest in reading and memorizing Qur'an at SDN 31 Pagaralam. To achieve the objectives, a qualitative approach was used with the type of research "field research." Research informants were principals, Islamic Religion teachers and students. The results of this study showed that, 1) the Islamic Religion teachers' strategies in increasing students' interest in reading and memorizing Qur'an at SDN 31 Pagaralam were that they created comfortable learning when $B T A$ activities took place; they gave motivation to students in the form of explanations and making them understand how important it was to memorize and read Qur'an for them especially for their lives in the world and in the hereafter; and they provided memorization targets through habituation, grading, and awarding, 2) Supporting factors for Islamic Religion teachers in increasing students' interest in reading and memorizing Qur'an were the students themselves, the role of teachers, and adequate facilities. Meanwhile the obstacle factors were the lack of time allocation, the lack of parental awareness, and negative technological influences.
\end{abstract}

Key Words: Strategy, Teacher, Interest 


\section{Pendahuluan}

Pendidikan merupakan salah satu aspek terpenting dalam kehidupan manusia, merupakan suatu alat terpenting untuk membentuk generasi yang siap menggantikan generasi tua guna untuk membangun masa depan, ini berarti bahwa setiap manusia berhak mendapat dan berharap untuk selalu berkembang dalam pendidikan. Pendidikan merupakan kebutuhan manusia, kebutuhan ini tidak bisa digantikan dengan yang lain, karena dengan pendidikan manusia akan mudah untuk mengembangkan kualitas, potensi dan bakat yang ada didalam diri manusia.

Undang-Undang Republik Indonesia Nomor 20 Tahun 2003 tetang Sistem Pendidikan Nasional menyatakan bahwa jabatan guru sebagai pendidik merupakan jabatan profesional. Dengan demikian profesionalisme guru dituntut terus berkembang sesuai dengan perkembangan zaman, perkembangan ilmu pengetahuan dan teknologi, serta kebutuhan masyarakat. Oleh karena itu, sudah menjadi keharusan bagi guru untuk terus berinovasi menemukan strategi yang tepat dalam proses pembelajaran sehingga perkembangan tersebut lebih bermakna, baik bagi guru maupun siswa. Guru yang profesional adalah guru yang memiliki keahlian sebagai guru, tidak hanya memenuhi berbagai kualifikasi, baik kepribadian, kemampuan mengajar, penguasaan spesialisasi dalam bidang studi tertentu, tetapi juga harus memiliki kemampuan dalam rangka pengembangan kurikulum sesuai fungsi manajemen (Hamalik. 2010: 20).

Dalam upaya pencapaian tujuan kurikulum tersebut, guru merupakan komponen pengajaran yang memegang peranan penting karena salah satu tugas pokoknya adalah mengajar..

Keberhasilan pendidikan tidak luput dari proses pembelajaran. Di antaranya adalah strategi pembelajaran yang di dalamnya terdapat metode dan teknik. Pemilihan strategi pembelajaran yang sesuai materi, keadaan dan kemampuan siswa akan membuat proses pembelajaran lebih optimal. Strategi pembelajaran merupakan komponen yang penting dalam setiap kegiatan pembelajaran. Oleh karena itu, dengan penggunaan strategi yang tepat dalam pembelajaran, akan tercapai tujuan secara maksimal.

Peranan strategi pembelajaran pada kegiatan pembelajaran yang optimal akan mengefektifkan proses tersebut, semakin efektifnya proses, semakin tinggi pula hasil yang akan dicapai. Adanya kurikulum yang disusun dengan baik belum tentu akan berpengaruh banyak pada prestasi peserta didik, jika tidak didukung oleh strategi pembelajaran yang sesuai (Zamroni, 2010: 74-75). Belajar yang tidak menggairahkan bagi peserta didik biasanya lebih banyak mendatangkan kegiatan pembelajaran yang 
kurang efektif. Tentu saja hal ini menjadi kendala bagi tercapainya tujuan pembelajaran (Djamarah dan Zain, 2010: 7).

Sebagai seorang penyampai pesan atau materi pelajaran, guru dituntut untuk senantiasa kreatif dan inovatif dalam proses pembelajaran agar dapat membangkitkan minat belajar siswa. Berhasil atau tidaknya kurikulum pendidikan yang telah direncanakan/ditetapkan kuncinya adalah terletak pada proses belajar mengajar sebagai ujung tombak dalam mencapai sasaran (Nurdin, 2002: 57). Proses belajar akan berjalan dengan lancar apabila ada minat. Oleh karena itu, guru harus mampu meningkatkan minat siswa dalam membaca dan menghafal Alquran.

Berdasarkan hasil observasi awal di SDN 31 Pagaralam, Guru Pendidikan Agama Islam di SDN 31 Pagaralam berjumlah 2 orang sedangkan kelas dari jenjang kelas 1 hingga kelas 6 yang terdapat di sekolah tersebut berjumlah 10 kelas, di kuatkan oleh peneliti di lapangan bahwa sebagian siswa yang tidak pernah belajar membaca Alquran karena keluarga (orang tua) tidak pernah mengajari atau memasukkannya ke TPQ yang ada di lingkungannya. Sebagian siswa yang lain didapati karena memang tidak mau mengaji dengan alasan malas, oleh karenanya guru diharapkan berperan dalam meningkatkan minat membaca dan menghafal Alquran.

Faktor-faktor di atas ikut mempengaruhi kecenderungan dan sikap masa bodoh serta tanggapan bahwa belajar membaca dan menghafal Alquran itu sulit. Sudah menjadi rahasia umum bahwa minat untuk membaca dan menghafal Alquran di kalangan anak-anak muslim Indonesia saat ini mulai berkurang, demikian pun dilingkungan SDN 31 Pagaralam, kurangnya minat membaca dan menghafal Alquran ini disebabkan beberapa faktor. Pada akhirnya, menjadi tugas guru PAI-lah untuk berupaya menyiapkan strategi dalam meningkatkan minat siswa untuk membaca dan menghafal Al-quran pada siswa tersebut.

Berbagai macam permasalahan yang telah dikemukakan pada latar belakang masalah, maka penulis ingin mendalami strategi di SD Negeri 31 Pagaralam, Melihat kondisi yang demikian, hal inilah yang menjadi motivasi utama peneliti untuk melakukan penelitian lebih lanjut tentang Strategi Guru PAI Dalam Meningkatkan Minat Membaca dan Menghafal Alquran Pada Siswa di SDN 31 Pagaralam.

\section{Kajian Literatur}

Pengertian Strategi menurut (Djamarah dan Zain, 1997: 3), adalah secara umum strategi mempunyai pengertian "suatu garis-garis besar haluan" untuk bertindak dalam usaha mencapai sasaran yang telah ditentukan. Dihubungkan dalam belajar mengajar strategi bisa di artikan sebagai pola-pola umum kegiatan guru dan 
anak didik dalam perwujudan kegiatan belajar mengajar untuk mencapai tujuan yang digariskan. Pemahaman ini berarti bahwa minat muncul melalui proses kesadaran seseorang dalam mendeskripsikan suatu objek yang memiliki hubungan dengan dirinya baik secara langsung ataupun tidak langsung.

Strategi pembelajaran harus mengandung penjelasan tentang metode dan tehnik yang digunakan selama proses pembelajaran berlangsung. Pemilihan strategi pembelajaran sangatlah penting, artinya bagaimana pendidik dapat memilih kegiatan pembelajaran yang paling efektif dan efesien untuk menciptakan pengalaman belajar yang baik. Oleh karena itu dibutuhkan kreatifitas pendidik dalam memilih dan menggunakan strategi pembelajaran yang disusun berdasarkan karakteristik peserta didik dan situasi kondisi yang dihadapinya. Menurut Riyanto (2012) yang dimaksud dengan strategi adalah suatu rencana tentang pendayagunaan dan penggunaan potensi dan sarana yang ada untuk meningkatkan efektifitas dan efesien pengajaran". Secara umum strategi mempunyai pengertian suatu garis yang besar haluan untuk bertindak dalam usaha mencapai target yang telah ditentukan. Menurut Dick dan Carey dalam Syaifurrahman dan Ujiati (2013) bahwa strategi pembelajaran adalah komponenkomponen dari suatu set materi termasuk aktivitas sebelum pembelajaran, dan partisipasi peserta didik yang merupakan prosedur pembelajaran yang digunakan kegiatan selanjutnya' (Erna Supiyani, Jurnal Pencerahan, Vol. 10, No. 1, Maret, 2016: 41).

Strategi belajar mengajar perludirancang dan diterapkan guruketika akan dansaat melaksanakan pembelajaran. Dengan strategi pembelajaran yang baik, tentunya akan dapat dihasilkan hasil pembelajaran yang maksimal. Siswa dapat belajar dengan nyaman, karena gurunya mengajar dengan empati, strategi menghadirkan hati, menyampaikan pentingnya materi untuk kehidupan masa mendatang bagi siswa, danjuga memahami bentuk-bentuk materi pelajaran yang disampaikannya. Dengan pemahaman ini, guru dapat menentukan strategi yang cocok yang sesuai dengan bentuk materi, mungkin saja berupa konsep, fakta, dalil atau rumus (Ikbal Barlian, Jurnal Forum Sosial, Vol. VI, No. 01, Februari, 2013: 246)

Dalam khazanah pemikiran Islam istilah guru memiliki beberapa istilah seperti "ustadz, muallim, muaddib, dan murabbi. Beberapa istilah untuk sebutan "guru" itu terkait dengan beberapa istilah untuk pendidikan, yaitu ta'lim, ta'dib, dan tarbiyah. Istilah muallim lebih menekankan guru sebagai pengajar dan penyampai pengetahuan dan ilmu, istilah muaddib lebih menekankan guru sebagai pembina moralitas dan akhlaq peserta didik dengan keteladanan, istilah murabbi lebih menekankan pengembangan dan pemeliharaan baik aspek jasmaniah maupun 
ruhaniah. Sedangkan istilah yang umum dipakai dan memiliki cakupan makna yang luas dan netral adalah ustadz yang dalam bahasa indonesia diterjemahkan sebagai guru. Kedudukan orang alim atau guru dalam Islam dihargai tinggi bila orang itu mengamalkan ilmunya. Mengamalkan ilmu dengan cara mengajarkan ilmu itu kepada orang lain adalah suatupengamalan yang paling dihargai oleh Islam. Karena bisa memberkan ilmu kepada yang membutuhkan. Guru memiliki banyak tugas, baik yang terikat oleh dinasmaupun di luar dinas, dalam bentuk pengabdian. Ada tiga jenis tugas guru, yakni tugas dalam bidang profesi (mendidik, mengajar, dan melatih), bidang kemanusiaan (menjadi orang tua kedua), bidang kemasyarakatan (mencerdaskan bangsa indonesia) (Moch Yasyakur, Jurnal Edukasi Islami, Vol. Januari. 2016: 1191).

Minat adalah suatu keadaan dimana orang mempunyai perhatian terhadap suatu objek disertai keinginan untuk mempelajari maupun membuktikan objek tersebut lebih lanjut. Sedangkan Winkel (2005:212) menyatakan minat belajar adalah kecenderungan subjek yang timbul untuk merasa tertarik pada bidang studi atau pokok bahasan tertentu, merasa senang mempelajari materi itu.Dan disimpulkan bahwa minat membaca merupakan keadaan dimana anak mempunyai perhatian, keinginan dan rasa senang terhadap mata pelajaran itu.Minat baca ialah perasaan tertarik pada suatu topik yang sedang dibahas atau dipelajari; untuk itu kerap digunakan istilah "perhatian". Ini bisa diartikan suatu rasa lebih suka dan rasa keterikatan pada suatu hal atau aktivitas, tanpa ada yang meyuruh. Minat pada dasarnya adalah penerimaan akan suatu hubungan antara diri sendiri dengan sesuatu diluar diri. Semakin kuat atau dekat hubungan tersebut, semakin besar minatnya. Dapat disimpulkan bahwa minat belajar merupakan keadaan dimana santri mempunyai perhatian, keinginan dan rasa senang terhadap mata pelajaran itu.Minat membaca adalah suatu perhatian yang kuat dan mendalam disertai dengan perasaan senang terhadap kegiatan membaca sehingga dapat mengarahkan seseorang untuk membaca dengan kemauannya sendiri (Husna Welly Anggraini, Jurnal Fisif, Vol. 3, No. 2, Oktober. 2016: 6).

\section{Metodologi Penelitian}

Jenis penelitian ini merupakan jenis penelitian deskriptif kualitatif dalam buku Lexy J. Moleong (2007:6) menyatakan pendekatan kualitatif artinya penelitian yang bermaksud untuk memahami fenomena tentang yang dialami oleh subjek penelitian misalnya perilaku, persepsi, motivasi, tindakan, dll. Sumber data penelitian ini yaitu sumber data primer dan data sekunder. Data primer dalam penelitian ini adalah hasil 
wawancara dan observasi. Data wawancara bersumber dari kepala sekolah, dan guru, dan siswa. Data sekunder merupakan hasil pengumpulan data dari dokumen sekolahnya. Teknik pengumpulan data dalam penelitian ini adalah yang pertama wawancara, observasi, dan dokumentasi. Sedangkan teknik pengolahan data dan analisis data yaitu reduksi data, penyajian data, verifikasi atau penarikan kesimpulan dan triangulasi data.

\section{Hasil dan Pembahasan}

Strategi merupakan cara atau tindakan yang dijadikan acuan untuk mencapai keberhasilan suatu tujuan. Dalam pendidikan strategi merupakan poin yang sangat penting dalam mewujudkan keberhasilan dari tujuan pendidikan yang ditentukan. Dalam pelaksanaan suatu program tentunya strategi juga menempati posisi yang sangat penting, dimana dengan strategi yang tepat maka hasil akan maksimal. Termasuk untuk meningkatkan minat membaca dan menghafal Alquran Pada siswa di SDN 31 Pagaralam akan berhasil secara maksimal dengan strategi yang tepat. Dalam kebijakan keunggulan sekolah, disebutkan bahwa sekolah menanamkan pendidikan karakter islami berakhlak dan berbudi pekerti.

BTA diadakan di sekolah untuk diperkenalkan pada siswa dalam kesehariannya dan dibiasakan untuk selalu membaca Alquran dan belajar dasar-dasar keislaman. Jika nilai-nilai qur'ani pada anak sudah terbentuk maka akan lebih mudah bagi kami seorang guru dalam membenahi akhlak dan pribadi siswa sehingga siswa diharapkan ketika lulus dari sekolah ini sudah bisa membaca dan menghafal Alquran (Juz Amma) dengan baik. Hal ini yang menjadi tuntunan seluruh warga sekolah untuk mensukseskan program BTA yaitu rasa tanggung jawab sebagai pengajar kepada anak didiknya agar menjadi generasi yang Qur'ani dan bisa memiliki bekal untuk dirinya. Dengan menanamkan nilai-nilai Qur'ani dalam diri siswa akan mempermudah bagi seorang guru dalam membenahi akhlak dan pribadi siswa untuk menjadi manusia yang berakhlakul karimah.

Untuk strategi yang dilakukan oleh guru PAI dalam meningkatkan minat membaca dan menghafal Alquran pada siswa kelas VI, sebenarnya tidak ada strategi khusus yang kami lakukan mbak, yang kami lakukan sebagai guru, yaitu yang pertama kami mengajak mereka bernyanyi lagu-lagu islami kemudian sholawat semua itu kami lakukan semata-mata untuk membangkitkan rasa nyaman ataupun suka/tertarik ketika program berlangsung kemudian menanyakan aktifitas apa yang siswa kerjakan sebelum masuk ruangan tadi, kemudian membaca Al-fatihah bersamasama, doa sebelum membaca Alquran dan kemudian mengajak siswa membaca 
Alquran dengan guru membaca seayat-seayat kemudian siswa mengikutinya, kemudian memberi pengertian atau arahan kepada siswa bahwa membaca dan menghafal Alquran itu sangat penting, dan memberi nasehat berupa bahwa suatu saat nanti hafalan tersebut akan berguna untuk kehidupan mereka sehari-hari apalagi yang putra kan nanti suatu saat akan menjadi imam sholat begitupun yang putri untuk bacaan waktu mereka sholat.

Terdapat beberapa strategi yang dilakukan oleh guru PAI untuk meningkatkan minat membaca dan menghafal Alquran (Juz 'Amma). Adapun strategi yang dilakukan oleh guru PAI adalah sebagai berikut.

Berdasarkan pengamatan peneliti, diketahui bahwa salah satu strategi untuk meningkatkan minat membaca dan menghafal Alquran siswa adalah dengan cara memberi motivasi, pengertian bahwa betapa pentingnya Alquran di hidup kita karena Alquran adalah pedoman bagi umat muslim, maka dari itu membaca dan menghafal Alquran itu sangat penting untuk kehidupan mereka masing-masing dan untuk bekal mereka di kemudian hari dan bagi laki-laki suatu saat mereka akan menjadi imam sholat jadi setidaknya sudah mempunyai hafalan Alquran (Juz Amma). siswa harus hafal sekian surat yang sudah ditentukan dari guru, memberi motivasi kepada siswa. Motivasi dari guru ini berupa penguatan atau nasehat kepada siswanya bahwa sangat pentingnya membaca dan menghafal Alquran untuk dirinya di kehidupan sehari-hari mentarget hafalan bagi seluruh siswa di kelas IV, siswa harus hafal sekian surat yang sudah ditentukan dari guru.

Anak-anak tidak hanya hafal-hafal saja tetapi benar-benar diperhatikan tajwidnya, panjang pendeknya

Berdasarkan pernyataan tersebut, diketahui bahwa salah satu strategi guru PAI dalam meningkatkan minat hafalan siswa yaitu dengan cara memperhatikan bacaan hafalan siswa. Dengan memperhatikan tajwid, makharijul hurufnya dan panjang pendeknya akan dapat membantu siswa dalam proses menghafalnya tentunya bacaan siswa semakin baik. Bila bacaannya sudah baik sudah pasti hafalan siswa juga akan lebih baik. Tentunya tidak sembarang guru dapat menjadi instruktur yang dapat membimbing, mengarahkan dan menyimak penghafalan Alquran

Melalui Pembiasaan Di SDN 31 Pagaralam ini, dalam upaya meningkatkan minat membaca dan menghafal Alquran dengan melakukan tindakan salah satunya melalui pembiasaan sebagai kegiatan rutin siswa membaca Alquran di sekolah, yaitu menyuruh siswa untuk membaca Alquran setiap kali pelajaran pendidikan agama 
Islam setelah guru selesai menyampaikan materi yang telah diajarkan. Sebagaimana yang dijelaskan oleh Ibu Lamiati selaku guru agama kelas 6, berikut :

"Setiap kali pelajaran pendidikan agama Islam setelah guru selesai menyampaikan materi di kelas, selalu kami sisakan waktu setengah jam untuk dibuat anak-anak membaca Alquran (wawancara dengan ibu lamiati).

Dengan penanaman pembiasaan ini sangat membantu anak untuk cinta membaca dan menghafal Alquran terutama anak yang Dengan adanya pembiasaan tersebut, diharapkan anak-anak untuk lebih minat dalam membaca dan menghafal Alquran. Dan ketika peneliti menanyakan tujuan dari penerapan tersebut beliau menjelaskan:

"Hal ini dilakukan agar mereka terbiasa melakukan aktivitas yang diawali dengan hal-hal yang baik, kemudian melatih agar terbiasa membaca Alquran karena kebanyakan anak jarang membaca Alquran dirumah. Disinilah tanggung jawab guru PAI bagaimana caranya menumbuhkan kecintaan terhadap Alquran" (wawancara dengan ibu Tesna Dewi).

Melalui Pemberian Point/nilai di sini guru pendidikan agama Islam juga menerapkan pemberian nilai yang biasanya diistilahkan dengan "Poin" dalam upaya meningkatkan minat membaca dan menghafal Alquran. "Guru memberikan poin kedalam daftar nilai setelah siswa selesai membaca Alquran, dan juga memberikan poin ketika hafalan surat-surat pendek sesuai batas hafalannya" (observasi tanggal 11 september 2017).

"Dalam meningkatkan minat membaca dan menghafal Alquran, saya selalu memberikan poin/nilai sebagai penilaian dari kegiatan mengajar Alquran. Biasanya saya memberikan poin-poin tersendiri untuk menambah semangat siswa" (wawancara dengan ibu Tesna Dewi).

Dari uraian di atas, begitu jelas bahwa pemberian poin atau nilai yang dilakukan oleh guru pendidikan agama Islam di SDN 31 Pagaralam ini merupakan salah satu bentuk dalam meningkatkan minatm semangat siswa untuk lebih giat membaca dan menghafal Alquran. Karena terlihat jelas bahwa dengan adanya pemberian poin tersebut mampu menggerakkan siswa untuk melaksanakan apa yang telah ditugaskan oleh guru.

Untuk menunjang proses belajar pada siswa dalam hal ini kaitannya membaca dan menghafal Alquran sangat diperlukan. Walaupun pemberian nilai tidak mutlak bisa dijadikan acuan untuk mengukur kemampuan siswa. Tetapi tidak ada salahnya dilakukan apabila hal ini dapat meningkatkan minat pada siswa itu sendiri. 
Melalui Pemberian Penghargaan di SDN 31 Pagaralam ini, salah satu bentuk upaya guru pendidikan agama Islam dalam meningkatkan minat membaca dan menghafal Alquran dengan cara memberikan penghargaan. Penghargaan yang dimaksud disini bisa berupa hadiah, tepuk tangan dan kata-kata sanjungan atau pujian. "Guru PAI memberikan pujian kepada siswa yang bagus hafalannya dan yang poin hafalannya banyak" (observasi tanggal 11 September 2017).

Sebagaimana yang telah diutarakan oleh Ibu Tesna Dewi selaku guru PAI, berikut ungkapan beliau:

"Upaya yang kami lakukan dalam meningkatkan minat membaca dan menghafal Alquran yaitu dengan memberikan penghargaan bagi siswa yang aktif dan berprestasi. Semisal ketika saya menyuruh siswa untuk menghafal surah an-Naas, siapa yang nantinya dapat menghafalkannya dan sudah benar hafalannya akan mendapat pujian dari ibu guru, Bagus/Pintar nak..." (wawancara dengan ibu Tesna Dewi).

Upaya yang dilakukan ini merupakan bentuk penghargaan yang diberikan oleh guru kepada siswa walaupun hanya berupa kata-kata ataupun hanya mengeluselus kepala siswa. Tetapi hal ini dapat mendorong siswa untuk lebih giat belajar, karena mereka merasa diperhatikan dan dipuji di depan teman-temannya.

\section{Kesimpulan}

Dari serangkaian pembahasan di atas dapat ditarik kesimpulan bahwa strategi yang dilakukan oleh guru PAI dalam meningkatkan minat membaca dan menghafal Al-Quran pada siswa di SDN 31 Pagaralam yaitu menciptakan pembelajaran yang nyaman ketika BTA berlangsung kemudian memberikan motivasi kepada anak betapa pentingnya menghafal dan membaca Al-Quran, kemudian memberikan target hafalan, ada juga metode yang dilakukan oleh guru PAI yaitu melalui pembiasaan, kemudian melalui pemberian point (nilai), lalu melalui pemberian penghargaan dengan demikian akan membuat minat siswa bangkit dalam membaca dan menghafal AlQuran.

Faktor pendukung guru PAI dalam meningkatkan minat membaca dan menghafal Al-Quran pada siswa yaitu, peserta didik itu sendiri. Mereka akan senang belajar apabila dalam dirinya timbul keinginan atau adanya kesadaran dalam diri siswa tersebut betapa pentingnya membaca dan menghafal Al-Quran, peran seorang guru dan kemudian fasilitas yang memadai, sedangkan faktor penghambat yaitu, kurangnya alokasi waktu, kurangnya kesadaran orang tua, kemudian pengaruh negatif teknologi 


\section{Daftar Pustaka}

Anggraini, H. W. Komunikasi Instruksional Guru Dalam Meningkatkan Minat Membaca dan Menghafal Alquran di Maqdis Kota Duri Kecamatan Mandau Kabupaten Bengkalis. Jom Fisif, (Vol. 3, No. 2, 2016).

Barlian, I. Begitu Pentingkah Strategi Belajar Mengajar Bagi Guru. Jurnal Forum Sosial, (Vol. VI, No. 01, 2013).

Djamarah, S. B. \& Aswan, Z. (2010). Strategi Belajar Mengajar. Jakarta: Rineka Cipta.

Erna, S. Implementasi Manajemen Pembelajaran Alquran di Sekolah Dasar Islam Terpadu Nurul Ishlah Banda Aceh. Jurnal Pencerahan, (Vol. 10, No. 1, 2016).

Hamalik, O. (2010). Pendidikan Guru: Berdasarkan Pendekatan Kompetensi. Jakarta: Bumi Aksara.

Moleong, L. (2007). Metodologi Penelitian Kualitatif. Bandung: Remaja Rosdakarya.

Nurdin, M. (2002). Moral dan Kognisi Islam. Bandung: Alfabeta.

W.S. Winkel. (2005). Psikologi Pengajaran. Yogyakarta. Media Abadi.

Yasyakur, Moch. Strategi Guru PAI Dalam Menanamkan Kedisiplinan Beibadah Sholat Lima Waktu. Jurnal Edukasi Islami, (Vol. 05, 2016).

Zamroni. (2010). Pendidikan Masa Depan. Yogyakarta: Bigraf Publising. 